\title{
Effect of Artificial Defoliation in Different Levels on Agronomic Characteristics in Corn Culture
}

\author{
Vitor Gustavo Kuhn ${ }^{1}$, Jonas Kestring ${ }^{2}$, Carlos Alberto Pagnocelli ${ }^{2}$, Jaqueline de Araujo Barbosa ${ }^{1}$, Neusa Kuhn ${ }^{1}$, \\ Magno Daniel Porfirio ${ }^{3}$, Silvio Douglas Ferreira ${ }^{1}$, Guilherme Mascarello ${ }^{1}$, Paulo Eduardo Follmann ${ }^{1}$ \\ $\&$ Marcelo Augusto Pastori ${ }^{1}$ \\ ${ }^{1}$ Postgraduate Program in Agronomy, State University of the West of Paraná, Marechal Cândido Rondon, PR, \\ Brazil \\ ${ }^{2}$ School of Agricultural Sciences, University Center Union Dynamics of the Cataracts, Brazil \\ ${ }^{3}$ Postgraduate Program in Zootechnics, State University of the West of Paraná, Marechal Cândido Rondon, PR, \\ Brazil \\ Correspondence: Vitor Gustavo Kuhn, Postgraduate Program in Agronomy, State University of the West of Paraná, \\ Marechal Cândido Rondon, PR, Brazil. Tel: 55-45-99145-5152. E-mail: vitorg.2016@hotmail.com
}

Received: September 28, 2017

Accepted: November 5, 2017 Online Published: December 15, 2017

doi:10.5539/jas.v10n1p336

URL: https://doi.org/10.5539/jas.v10n1p336

\begin{abstract}
The objectives of the present work were to evaluate the effects caused by defoliation at different levels in the corn crop, evaluating the agronomic characteristics and yield of maize. The experiment was conducted in the period from September to January, harvest 2016/2017. The experimental design was a randomized block, consisting of five treatments composed of different levels of defoliation of corn plants with four replicates: T1: Witness, without defoliation of plants; T2: Removal of all leaves of the plant; T3: leaves only in the lower third of the plant; T4: Leaves only in the middle third of the plant; T5: Leaves only in the upper third of the plant. Defoliation procedures were performed at the beginning of the VT reproductive stage of maize. The following parameters were evaluated: Spike insertion height; Diameter of the stem; Ear length; Spike diameter; Number of rows of grains on the spike; Number of grains in row; Final Productivity; Weight of a thousand seeds. The results were significant in almost all analyzed variables, where superior results were obtained by the T1 control, followed by T4. It was concluded that the best results were obtained by the control in which there was no defoliation, but there was no significant difference with the results obtained by the treatment in which there were only leaves in the middle third of the plant. From these results it can be affirmed the great importance of the median leaves above and below the spike insertion.
\end{abstract}

Keywords: importance of leaves, Zea mays, productivity

\section{Introduction}

Used worldwide for animal feed corn has great diversity in its use, ranging from animal feed and human to the high technology industry (Miranda et al., 2012). Possessing great economic and social importance, there was an increase in the total corn production area under conventional management, from 15,922.5 ha in the 2015/2016 harvest to 17,244.4 ha in the 2016/2017 harvest (CONAB, 2017).

Maize production exists in practically all of Brazil, with $92 \%$ of the production concentrated in the South (32.2\%), Southeast (17.7\%) and Central-West (41.7\%) regions. However, it is observed that the average yield of maize in Brazil, when compared to that obtained by the large world producers, reflects a lower technological level, this is due mainly to the cultivation of the second crop is carried out in a period of higher incidence of diseases like (Miranda et al., 2012).

The yield of maize in Brazil is very far from the productive potential of the crop, where one of the main causes for the problem between the actual yield and the potential is the decrease of the photosynthetically active surface of the crop, caused by defoliation. The loss of leaves limits the interception of solar radiation and the production of photoassimilates, especially when it reaches maize in the phase close to flowering (Lauer, 2004).

The biotic or abiotic factors that cause the fall of leaves are directly related to the productivity of the crop, because the leaves are fundamental in the accomplishment of photosynthesis, consequently in the production of 
photoassimilates, functioning as a source, in a source-drain relationship, where the developing spike functions as a drain so that the filling of grains occurs, being the loss of leaves very damaging to the corn crop (Manfron et al., 2003).

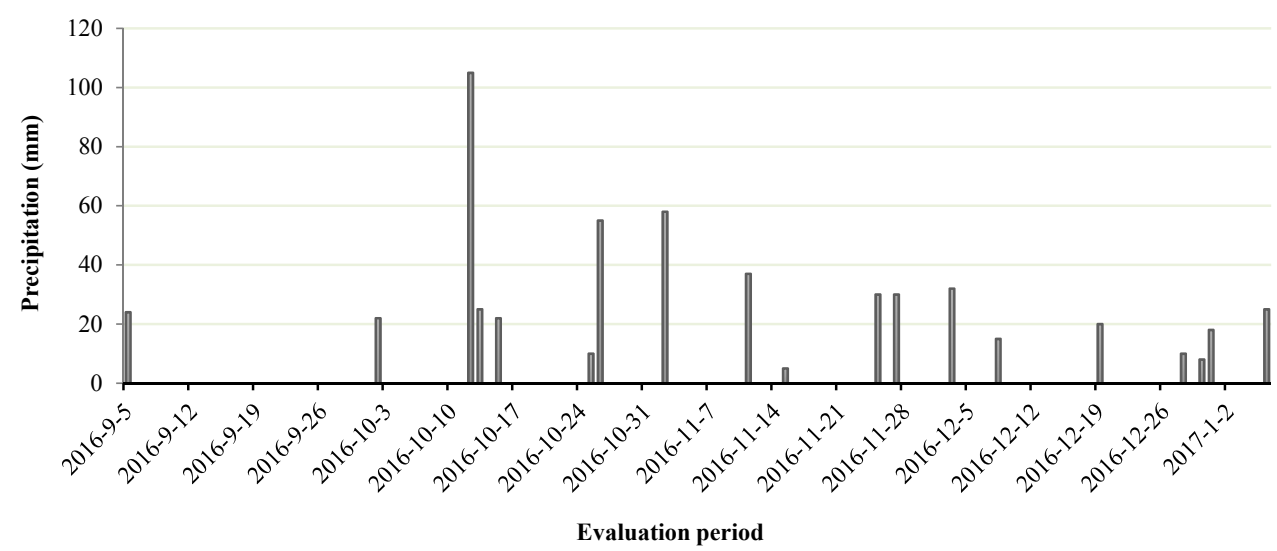

Figure 1. Precipitation during the period of conduction of the experiment

Defoliation from hail, frost or wind rain in the initial stages of maize has little or no effect on crop productivity (Magalhães \& Durães, 2006).

The leaf area usually increases as the plant emits new leaves until it reaches the maximum of leaves. The yield potential of maize grains will depend mainly on the amount of incident solar radiation, interception efficiency, intercepted radiation conversion, and assimilation efficiency of the grains (Forsthofer et al., 2006).

The leaves inserted in the various positions of the stem contribute in different ways in the supply of metabolites to the other parts of the plant. (Fornasieri Filho, 2007). In addition, corn grain yield potential will depend primarily on the amount of incident solar radiation and the efficiency of interception and conversion of the intercepted radiation in phytomass and the partition efficiency of assimilated to the structure of economic interest (Sangoi et al., 2012).

Leaf maintenance is extremely important because it is the main organ responsible for photosynthesis and photoassimilates production. In addition, the crop has low capacity to compensate foliar losses (Pereira et al., 2012). The loss of leaves by the plant is a stress that impairs the development of the crop, because it reduces the leaf area of the plant and consequently limits the interception of the solar radiation, reducing the photosynthetic capacity and the biomass production (Picoli Junior, 2011).

The corn crop has low capacity to compensate for leaf losses, since its effective capacity to compensate for spaces and leaf plasticity are reduced (Pereira et al., 2012).

According to Fancelli and Dourado Neto (2004), the total destruction of the leaves when the crop presents eight expanded leaves, due to the occurrence of hail, frost, severe attack of pests and diseases, decreases the productivity between 10 to $25 \%$.

Losses in production may be directly related to the fall of the leaves of the plant, which drastically reduces the photosynthetic capacity of the plant, harming the translocation of photoassimilates to the grains, information about the behavior of the leaves in different positions can be of great importance mainly in conditions in which defoliation occurs both by insects and also by hail rains, and it may be of great value at the moment of the evaluation of leaf losses to know which leaves play a fundamental role at the time of filling the grains of the crop.

The objectives of the present study were to evaluate the effects caused by artificial defoliation at different levels, evaluating the agronomic characteristics and yield of the maize crop.

\section{Material and Methods}

The field experiment was carried out in the community Nova Brasília, located in the interior of the municipality of São Miguel do Iguaçu, located at latitude $25^{\circ} 18.366^{\prime} \mathrm{S}$, longitude $54^{\circ} 16.349^{\prime} \mathrm{W}$, and altitude of 267 meters. 
The experiment was conducted in the period from September to January, harvest 2016/2017, and sowing was carried out on September 11, 2016.

The climate of the region, according to the classification of Koppen, is of type Cfa, with precipitations well distributed during the year (Caviglione et al., 2000). Characterized as humid subtropical mesothermic, with hot summers and winters with frost infrequent, with rainfall and average annual temperature of $1,500 \mathrm{~mm}$ and $21.4{ }^{\circ} \mathrm{C}$, respectively. The soil of the area is classified as Red Latosol Eutrophic of clay texture (Santos et al., 2013).

The experimental design was a randomized complete block (DBC), consisting of five treatments composed of different levels of defoliation of corn plants with four replicates: Treatment 1 (T1): Witness, without defoliation of the plants; Treatment 2 (T2): Removal of all leaves of the plant; Treatment 3 (T3): Leaves only in the lower third of the plant; Treatment 4 (T4): leaves only in the middle third of the plant; Treatment 5 (T5): Leaves only in the upper third of the plant.

The defoliation procedures were performed at the beginning of the VT reproductive stage of the corn, which marks the passage from the vegetative to the reproductive stage, when all leaves were fully developed. The defoliation process was performed manually with the aid of shears for cutting the leaves.

Each experimental plot was represented by five maize lines, spaced at $0.45 \mathrm{~m}$, with five meters in length, considering the three central lines, $1 \mathrm{~m}$ of each side of the plot was also disregarded for the composition of the useful area, which totaled $4.05 \mathrm{~m}^{2}$.

The material used was the simple hybrid LG 6033 VT PRO 2, the seeds were treated with Imidacloprid Thiodicarb at a dose of $300 \mathrm{~mL}$ to $100 \mathrm{~kg}$ of seeds, a population of 50,000 plants per hectare was adopted.

In the V6 stage (six fully developed leaves) the first application of mesosteric and systemic fungicide of the strobilurin and triazole groups (TRIFLOXYSTROBIN TEBUCONAZOL) at the dose of $0.75 \mathrm{~L} \mathrm{ha}^{-1}$ was carried out according to the product insert registered with ADAPAR, the second application was carried out with the same product in the VT stage, where after the removal of the leaves of each treatment the plants presented greater vulnerability to the infectious diseases, due to the occurrence of the damages caused by the defoliation, being able to interfere in the results of the present work.

For the basic fertilization of the crop were used $30 \mathrm{~kg} \mathrm{ha}^{-1}$ of $\mathrm{N}, 60 \mathrm{~kg} \mathrm{ha}^{-1}$ of $\mathrm{P}_{2} \mathrm{O}_{5}$, and $60 \mathrm{~kg} \mathrm{ha}^{-1}$ of $\mathrm{K}_{2} \mathrm{O}$ at the time of sowing, there were no applications of $\mathrm{N}$ and $\mathrm{K}$ under cover.

The evaluations of the agronomic characteristics of the crop, besides the mass of a thousand grains and the productivity $\left(\mathrm{kg} \mathrm{ha}^{-1}\right)$ were carried out during the period of physiological maturation and crop harvest.

The following parameters were evaluated: Height of spike insertion: with the aid of a scale, the measurement was made starting at the height of the soil until the spike was inserted, the same 10 plants were used to determine the height of plants and evaluated the same day; cut-off diameter: stems of 10 plants per plot in the working area were measured at a height of $10 \mathrm{~cm}$ from the soil, with the aid of a pachymeter; length of spike: spikes of 10 plants were measured in the useful area of each plot, with the help of a set; Spigot diameter: 10 ears were already stripped of plants from the useful area of the plots, with the aid of a pachymeter; number of rows of grain in the spike: manual counts of the number of rows of 10 plants were carried out in the useful area of each plot; number of grains in the row on the spike: the number of grains in the row of ten-plant spikes in the useful area of each plot were counted manually. Final yield: it was determined by the collection of the spikes of the useful areas of the plots and after the threshing the grains were weighed correcting the humidity to $13 \%$. The yield of grains was expressed in $\mathrm{kg} \mathrm{ha}^{-1}$.

Mass of 1000 grains For this determination, the recommendations of Brazil (2009) were followed using eight replicates of 100 seeds from each batch, where each sample was weighed individually and the results expressed in grams. The data of all evaluated characteristics were submitted to analysis of variance at the $5 \%$ probability level, and when significant were submitted to the 5\% Tukey test.

\section{Results and Discussion}

The average rainfall in the region during the period which the experiment was carried out, where there were no severe water deficits during the development of the crop, is not a factor influencing the results of the work.

Referring to Table 1, analyzing the length of spike (LS), it can be observed that the best result presented was in $\mathrm{T} 1$, but does not differ statistically from T4, which also does not differ from T3 and T5, the lowest result was obtained with the treatment refers to $\mathrm{T} 2$ where total defoliation was performed. The result in $\mathrm{T} 1$ was expected due to the greater number of leaves consequently greater interception of solar radiation in relation to the other 
treatments. The results can be explained due to the stage at which the leaves were responsible for the development of the spike that is relatively accelerated in this period, stresses during this period may be responsible for a lesser development (Magalhães \& Durães, 2006).

Table 1. Average length of spike (LS), stem diameter (SD), thatched diameter (TD), pin insertion height (PIH) for the different levels of defoliation

\begin{tabular}{|c|c|c|c|c|}
\hline Treatments & $\mathrm{LS}$ & ED & TD & $\mathrm{PIH}$ \\
\hline & \multicolumn{4}{|c|}{----} \\
\hline $\mathrm{T} 1^{2}$ & $17.62 \mathrm{a}^{1}$ & $4.70 \mathrm{a}$ & $2.30 \mathrm{a}$ & $137.75 \mathrm{a}$ \\
\hline $\mathrm{T} 2$ & $6.37 \mathrm{c}$ & $3.67 \mathrm{~b}$ & $1.82 \mathrm{~b}$ & $137.25 \mathrm{a}$ \\
\hline $\mathrm{T} 3$ & $14.62 \mathrm{~b}$ & $4.57 \mathrm{a}$ & $2.35 \mathrm{a}$ & $139.25 \mathrm{a}$ \\
\hline $\mathrm{T} 4$ & $15.75 \mathrm{ab}$ & $4.67 \mathrm{a}$ & $2.37 \mathrm{a}$ & $138.25 \mathrm{a}$ \\
\hline T5 & $14.25 \mathrm{~b}$ & $4.60 \mathrm{a}$ & $2.62 \mathrm{a}$ & $143.25 \mathrm{a}$ \\
\hline Residue & 0.86 & 0.02 & 0.02 & 30.87 \\
\hline General Average & 13.72 & 4.44 & 2.29 & 139.15 \\
\hline CV $(\%)$ & 6.76 & 3.05 & 6.50 & 3.99 \\
\hline
\end{tabular}

Note. ${ }^{1}$ Be lowercase letters in the column do not differ by Tukey test at $5 \% . \mathrm{T}^{2}$ (control, without defoliation), T2 (Removal of all leaves of the plant); T3 (leaves only in the bottom third of the plant); T4 (leaves only in the middle third of the plant); T5 (Leaves only in the upper third of the plant).

For the stem diameter variable (LS), treatments T1, T3, T4 and T5 did not differ statistically, only in T2 was obtained a lower result than the others. The same result was repeated in the stem diameter variable (ED), where $\mathrm{T} 2$ had no leaf. It is explained the results obtained, based on the fact that the plant in its nature uses stem reserves as a source for the formation of spikes and subsequent grain filling (Marchi, 2008). Where the plant did not have any leaf, the plant had to use the stem reserves as source for the formation of spikes and subsequent filling of grains. Similar results were obtained by Viecelli et al. (2011), also Magalhães et al. (1995) obtained similar results when dealing with the treatment in which total plant defoliation occurred.

In relation to the spike insertion height variable (SIH) (Table 1), no significant differences were found in any of the treatments, and can be explained by the fact that defoliation occurred between V18 and VT stages, where plant height, height insertion of spikes and number of internodes were already defined by the plant (Magalhães \& Durães, 2006).

Differently, Rezende et al. (2015) also evaluating the defoliation in maize plants but in V4 stage obtained results in which the defoliation of 4 or more leaves significantly reduced the height of spike insertion. Khaliliaqdam et al. (2012) also verified at the time of spike insertion, performing defoliation between stages V6 and V8 of the corn crop.

In relation to Table 2, referring to the variable number of grain row (NGR), no significant differences were obtained in any of the treatments. With this, it is observed that, the stage in which the defoliation was carried out, did not interfere in the number of rows of grains.

According to Magalhães and Durães (2006) the number of grain rows (NGR) is generally defined around the V8 stage, but the number of grains per row (NRG) is defined around the V17 stage.

In the results of the variable number of grains per row (NRG), T1 was statistically higher than the other treatments, but did not differ statistically from T4, which in turn did not differ from T3 and T5, with T2 being the treatment with the lowest NGF. Treatment with total defoliation (T2) presented a $65.96 \%$ lower result than the control, where T1 and T4 obtained the best results.

As can be observed even with the defoliation occurring in V18, significant differences were obtained between the levels of defoliation in relation to the control, with these results, it can be affirmed that the defoliation even in V18 is harmful to the plant in relation to the number of grains that forms in each row in the spikes. 
Table 2. Average results for number of grain rows (NGR), number of grains per row (NRG), mass of thousand grains (MMG), productivity (PROD)

\begin{tabular}{lllll}
\hline Treatments & NGR & NRG & MTG & PROD \\
\hline & & & $---\mathrm{g}---^{-1}$ & $---\mathrm{kg} \mathrm{ha}^{-1}---$ \\
$\mathrm{T}^{2}$ & $14.50 \mathrm{a}^{1}$ & $40.25 \mathrm{a}$ & $353.50 \mathrm{a}$ & $9746.91 \mathrm{a}$ \\
$\mathrm{T} 2$ & $14.50 \mathrm{a}$ & $13.75 \mathrm{c}$ & $213.25 \mathrm{~d}$ & $1419.75 \mathrm{c}$ \\
$\mathrm{T} 3$ & $15.50 \mathrm{a}$ & $35.25 \mathrm{~b}$ & $334.50 \mathrm{~b}$ & $7070.98 \mathrm{~b}$ \\
$\mathrm{~T} 4$ & $15.50 \mathrm{a}$ & $36.75 \mathrm{ab}$ & $339.00 \mathrm{~b}$ & $8329.01 \mathrm{ab}$ \\
$\mathrm{T} 5$ & $15.50 \mathrm{a}$ & $33.75 \mathrm{~b}$ & $325.00 \mathrm{c}$ & $7401.85 \mathrm{~b}$ \\
Residue & 0.80 & 2.77 & 11.65 & 97044.32 \\
General Average & 15.10 & 31.95 & 313.05 & 2751.45 \\
CV $(\%)$ & 5.92 & 5.21 & 1.09 & 11.32 \\
\hline
\end{tabular}

Note. ${ }^{1}$ Be lowercase letters in the column do not differ by Tukey test at $5 \% . \mathrm{T}^{2}$ (control, without defoliation), T2 (Removal of all leaves of the plant); T3 (leaves only in the bottom third of the plant); T4 (leaves only in the middle third of the plant); T5 (Leaves only in the upper third of the plant).

In a study by Alvim et al. (2010) where the defoliation was performed in the R2 stage, the authors did not find significant results for number of grains per row (NRG) nor for number of grain rows (NGR). This indicates that in the reproductive phase of the corn crop the effects of defoliation are not reflected in the cited variables.

For the variable mass of a thousand grains (MTG), presented in Table 2, it can be observed that T1 obtained superior results to the others, $\mathrm{T} 3$ and $\mathrm{T} 4$ in turn were superior in relation to $\mathrm{T} 5, \mathrm{~T} 2$ treatment as in the other variables already presented were lower than all other treatments. Thus, it can be stated that the leaves of the middle and lower third exert great influence on the filling and mass of the grains in the spike.

Fornasieri Filho (2007) states that about $50 \%$ of the photoassimilates accumulated in the corn grains come from the leaves located in the upper third of the plant and 30\% of the photosassilates are from the leaves located in the middle third and the rest of the leaves distributed in the basal part.

Grain development is a result of the balance between the plant ability to produce photoassimilates (source) for the grains and its own potential for the use of available substrates (Pereira et al., 2012). Thus, it can be affirmed that the loss of leaves by the corn plant directly affects the mass of grains, consequently being able to reduce the productivity of the area.

For the authors Subedi and Ma (2005) when all the leaves above the spike were removed soon after the laying, the number of grains per spike and the mass of grains were reduced by approximately 84 and $94 \%$, respectively.

Regarding productivity, the $\mathrm{T} 1$ treatment was statistically superior to the others, but it was not differentiated from $\mathrm{T} 4$, which also did not have statistical difference with $\mathrm{T} 3$ and $\mathrm{T} 5$, being these results superior to the $\mathrm{T} 2$ treatment, which obtained the lowest productivity result. It can be observed that, with the removal of all leaves (T2), the reduction in productivity was $85.43 \%$ and $82.95 \%$, respectively, compared to $\mathrm{T} 1$ and $\mathrm{T} 4$.

Differently Alvim (2010) obtained results contradictory to that of the present work, in relation to productivity where it obtained better results in plants in which the leaves of the upper third were maintained besides the control with all leaves.

Silva (2005) explains that the lower productivity is expected in plants with less leaves because the results are directly related to the length of the spikes and also to the number of grains per spike, which are also affected by the decrease of the photosynthetic area.

According to Pereira et al. (2012), the stresses caused by the defoliation of the plant alter the source and drain relation, causing the decrease of productivity consequently increasing economic losses.

From the results presented in the present work, it is possible to affirm the great importance of the leaves in the production potential of the maize crop, simulating different levels of defoliation, important results were observed when with the already established crop the field is submitted to climatic phenomena as per for example, hail or even severe defoliation of pests, it is possible to estimate losses through defoliation levels. 


\section{Conclusions}

From the results, it can be concluded that the defoliation at different levels has significant responses in the maize crop, and with total defoliation the plant drastically reduces its grain yield, a thousand grain mass (MMG), number of grains per row (NGF), stem diameter (DC), plus length (CE) and ear diameter (DE).

Height of spike insertion and number of rows of grains are not influenced by defoliation at the beginning of the reproductive stage.

Better results were obtained by the control in which there was no defoliation, but there was no significant difference with the results obtained by the treatment in which there were only leaves in the middle third of the plant. From these results it can be affirmed the great importance of the median leaves above and below the spike insertion.

\section{References}

Alvim, K. R. T., Britol, C. H., Brandão, A. M., Gomes, L. S., \& Lopes, M. T. G. (2010). Leaf area quantification and defoliation effect on maize production components. Rural Science, 40(5), 1-6. https://doi.org/10.1590/ S0103-84782010000500003

Brazil, Ministry of Agriculture. (2009). Livestock and Supply. Rules for seed analysis. Brasília: SNDA/DNDV/CLAV.

Caviglione, J. H., Kiihl, L. R. B., Caramori, P. H., \& Oliveira, D. (2009). Climate maps of Paraná. Londrina: IAPAR.

CONAB (National Supply Company). (2017). Follow-up of Brazilian crop: Agricultural monitoring (Eighth Survey).

Fancelli, A. L., \& Dourado Neto, D. (2004). Maize Production (2nd ed.). Guaíba: Livraria e Editora Agropecuária.

Fornasieri Filho, D. (2007). Corn crop manual. Jaboticabal: Funep.

Forsthofer, E. L., Silva, P. R. F., Strieder, M. L., Minetto, T., Rambo, L., Argenta, G., \& Sangoi, L. (2006). Agronomic and economic performance of maize at different management levels and sowing times. Pesquisa Agropecuária Brasileira, 41(3), 399-407. https://doi.org/10.1590/S0100-204X2006000300005

Khaliliaqdam, N., Soltani, A., Mir mahmoodi, T., \& Jadidi, T. (2012). Effect of leaf defoliation on some agronomical traits of corn. World Applied Sciences Journal, 20(4), 545-548. https://doi.org/10.5829/ idosi.wasj.2012.20.04.2498

Lauer, J. G., Roth, G. W., \& Bertram, M. G. (2004). Impact of defoliation on corn yield yield. Agronomy Journal, 96(s/n), 1459-1463. https://doi.org/10.2134/agronj2004.1459

Magalhães, P. C., \& Durães, F. O. M. (2006). Physiology of corn production. Sete Lagoas-Mg: Embrapa Maize and Sorghum.

Magalhães, P. C., Durães, F. O. M., \& Paiva, E. (1995). Physiology of corn plant. Sete Lagoas: EMBRAPA/CNPMS.

Manfron, P. A., Dourado Neto, D., Pereira, A. R., Bonnecarrére, R. A. G., Medeiros, S. L. P., \& Pilau, F. G. (2003). Modelo do índice de área foliar da cultura do milho. Revista Brasileira de Agrometeorologia, 11(2), 333-342.

Marchi, S. L. (2008). Interaction between defoliation and plant population in corn crop in the western region of Paraná. Marechal Cândido Rondon, Brazil.

Miranda, A. R., Duarte, O. J., \& Garcia, J. C. (2012). Production system-Corn cultivation (8nd ed.). Seven Lagoons, Corn and Sorghum.

Pereira, M. J. R., Bonan, E. C. B., Garcia, A., Vasconcelos, R. de L., Giacomo, K. dos S., \& Lima, M. F. (2012). Morphoagronomic characteristics of maize submitted to different levels of manual defoliation. Revista Ceres, 59(2), 200-205. https://doi.org/10.1590/S0034-737X2012000200008

Pícoli Junior, G. J. (2011). Nitrogen fertilization as a strategy to minimize stress caused by foliar defoliation and phytotoxicity in corn (Unpublished master's thesis, State University of Santa Catarina, Florianópolis). 
Rezende, W. S., Brito, C. H., Brandão, A. M., Franco, C. J. F., Ferreira, M. V., \& Ferreira, A. S. (2015). Development and productivity of maize grains submitted to defoliation levels. Pesq. Agropec. Bras., 50(3), 203-209. https://doi.org/10.1590/S0100-204X2015000300003

Santos, H. G., Ker, J. C., \& Anjos, L. H. C. (2013). Brazilian Soil Classification System (3rd ed.). Brasília: Embrapa Information Production; Rio de Janeiro: Embrapa Solos.

Silva, C. J. (2005). Influence of abiotic stresses on the reproductive phase of maize (p. 60, Masters Dissertation). Jaboticabal: UNESP.

Subedi, K. D., \& Ma, B. L. (2005). Ear position, leaf area and contribution of leaves to grain yield in conventional and leafy maize hybrids. Crop Science, 45(s/n), 2246-2257. https://oi.org/10.2135/ cropsci2004.0653

Viecelli, C. A., Fillwocks, J. M., \& Suzin, V. (2011). Effect of defoliation on maize productivity. Brazilian Journal of Applied Technology in Agrarian Sciences, 4(3), 179-190.

\section{Copyrights}

Copyright for this article is retained by the author(s), with first publication rights granted to the journal.

This is an open-access article distributed under the terms and conditions of the Creative Commons Attribution license (http://creativecommons.org/licenses/by/4.0/). 